\title{
The Effect of Total Physical Response Technique Toward the Students' Speaking Ability at the First Grade Students' of SMA Negeri 2 Kolaka
}

\author{
Lina Anisah \\ lina.anisah@gmail.com
}

\author{
Universitas SembilanBelas November
}

\begin{abstract}
This research presents the effect of the total physical response technique toward the students' speaking ability in the first grade of SMA Negeri 2 Kolaka. It was based on the research question" Is there any effect of total physical response technique toward the students' speaking ability at the first-grade students at SMA Negeri 2 Kolaka?. The objective of this research was found the data and information whether there is an effect of total physical response technique toward the students' speaking ability at the first grade of SMA Negeri 2 Kolaka. The design of this research was preexperimental design, which one group pretest and posttest design. The subject of this research was class $\mathrm{X}_{3}$ of SMA Negeri 2 Kolaka consisted of 22 students based on purposive sampling. The study consists of two variables; they are independent variable and dependent variable. The independent variable was Total Physical Response while the dependent variable was the students' speaking ability. The instrument of the research was an oral test, which is recommended by Ur (1996). The data were analyzed using inferential and descriptive statistics. The inferential statistic was used to examine the hypothesis, while the descriptive statistics were used to describe the students' characteristics score such as mean score, frequency, minimun and maximun score in both pretest and posttest sessions. Based on findings in this study, it was confirmed that the students' mean score of post-test $(3,9)$ is higher than the pre-test $(2,25)$. The standard deviation of post-test $(0,541)$ was smaller than the standard deviation of pretest $(0,668)$, and the value of $t$-count $(11,2)$ was more prominent than $t$ table $(2,080)$ at the significant level 0,05 and degree of freedom $=21$, it means that $\mathrm{H}_{0}$ was rejected and $\mathrm{H}_{1}$ was accepted. It can be concluded that there is an effect of total physical response technique toward the students' speaking ability at the first grade of SMA Negeri 2 Kolaka.
\end{abstract}

Keyword: Total Physical Response, Speaking, Ability 


\section{INTRODUCTION}

English is becoming more critical with the involvement of the government. In a language teaching- learning, we often talk about four basic language skills, such as: listening, reading, speaking, and writing. Speaking is productive in oral ability. Speaking consists of producing systematic verbal utterances to convey meaning between two people or more. Bailey (2005) states, speaking is an interactive activity in producing, receiving and processing utterances that have meaning to convey information. Same with Bailey, Chastain (1988) states that the students' ability to develop their speaking skills comes up with many problems when they are arranging communication in the classroom activities. One of them is the students do not know how to express their idea and also they are also too shy and afraid to take part in the conversation.

Furthemore, this also happened in SMA Negeri 2 Kolaka, especially in the first-grade senior high school. A brief short interview with the teacher who taught there mentioned that speaking is a serious problem in English for the students. Speaking seems like something"dangerous" for many students there. Interest the material and the media among others including the technique in teaching English. And the percentage of teaching English for the students is deficient. The data in observation shown that there are a total of 22 students in class as the subject at $\mathrm{X}_{3}$ of SMA Negeri 2 Kolaka. The resulting total of mean score was 55 categorized low. The highest score was 75, and the lowest score was 40 . Only 3 students got score $75(13,63 \%)$, then 5 students who got score $60(22,72 \%)$ and 5 students who got score $50(22,72 \%)$ and last 9 students got score $40(40,90 \%)$.

The researcher has been used the other way that can improve the students' ability in English speaking skills. One of the methods is total physical response. It is not only focused on enhancing students speaking ability but also improves the component of speaking ability, such as fluency for communication. In the process of learning, the English language, especially in speaking the students will face if they do not learn English before and they cannot communicate in the English language so that the student should practice their English. The researcher believes that the Total Physical Response can help the students improve their speaking ability. Marsh (2001) explain, the use of commands, orders or imperatives is the principal teaching technique of TPR technique to guide the students, and it demands physical action from the learners who are designed to reinforce comprehension of particular basic terms from the problems that explain before, the researcher want to research at the first grade of SMA Negeri 2 Kolaka. The researcher will be applied Total Physical Response technique to improve students speaking ability. TPR is a good technique because TPR is a language teaching built around the coordination between speech and action. It attempts to teach language through physical (motor) activity. By using TPR the students can enjoy their experience in learning to communicate in foreign language. The feeling of success and low anxiety facilitate learning when using TPR technique. The students think that language 
"learning" is fun and rewarding, and they can continue to learn without much stress and with must enjoy.

\section{LITERATURE REVIEW}

Richard and Rodgers (2001) stated that total physical response (TPR) is a language teaching method built around the coordination of speech and action. It is based on a model of how children learn their first language. In this case, TPR looks the way that children learn their native language. TPR is linked to the "Trace Theory of Memory in Psychology". It means that retracing can be done verbally (e.g. by rote repetition) and in association with motoric activity combine tracing activities, such as verbal rehearsal accompanied motor activity, hence increase the probability of successful recall."

The general objectives of TPR are to teach oral proficiency at a beginning level. Richards and Rodgers (2001). Another sub-goal of the method is introducing a new vocabulary item to the student through body movement, to arose the students to enjoy their experience in learning foreign language, to reduce the students stressed felling when they are studying a foreign language, to get the students to recognize or identify the word that has been thought, using comprehension as a means to speak, and using action-based drills is the imperative form.

Besides having a general objective as Richards and Rodgers says, TPR also has six principles. Nunan (1999) lists six principles of TPR likes; stimulating memory with psychomotor associations, comprehension before production, lowering the students' anxiety and stress reduction, inductive teaching of grammar, unobtrusive error correction in the early stage, and grammatical features and vocabulary items from the immediate classroom surroundings.

In the teaching speaking by using TPR, Asher (1986) used commands as the basis for TPR. The teacher or a more proficient student gives a commands, demonstrates the commands, and then students respond physically to the commands. Because students are actively involved and not expected to repeat the commands, anxiety is low, and student focus is on comprehension rather than production.

TPR is a well-known beginning ESL method, but TPR-based activities can be adapted and incorporated into the mainstream or multi-level classes, particularly in areas where visible directions can be given. For example, any science experiment can be an opportunity to involve beginners through TPR. TPR also provides a base for literacy development in the second language students learn to read the commands they followed.

In the teaching and learning process under TPR, Asher in Richard and Rodgers (2001) explains that TPR can proceed in six-way, they are; review, new command, other items introduce, role reversal, reading, and writing. Here, review means that students are moved with commands, e.g." Open your book " while new command means that the teacher introduces a new or various command to the student, e.g." Close your eyes.“" 
TPR have some benefit in teaching and learning processes they are; it is fun and easy, it does not require a great deal of preparation on the part of the teacher; it is an excellent tool for learning to speak and also the other skills; class size does not need to be a problem; and there is age barrier.

\section{METHOD}

The research design is pre-experimental with one group pretest and posttest design. It means that only compare the result of pretest and posttest in one clas treatment (Isaac and Michael, 1981). In this study the dependent variable is the speaking ability, and the independent variable is TPR itself. A population is a group to which the results of the study are intended to apply (Best, 1981). The population of this study was the first-grade students of SMA Negeri 2 Kolaka who register in academic year 2015/2016. The total number of population consisted of four classes parallel they are $\mathrm{X}_{1}, \mathrm{X}_{2}, \mathrm{X}_{3}$, and $\mathrm{X}_{4}$. The total population was 90 students.

Frankel and Wallen (1990) give a description; a sample is a group in a research study on which information is obtained. The researcher used " purposive sampling" method to choose the study samples. Arikunto (2010) stated that " to avoid spending much time, power and cost, it is better purposive sampling." It means that the distributions of the students' class performance neglected and determine directly. Besides, the placement of the students in a class was not based on their rapport. Based on those reasons, the researcher chose one class directly $\mathrm{X}_{3}$, which consisted of 22 students.

The instrument that the researcher used in this research was the speaking test, in which the students were instructed to give command to the picture provided. The researcher uses a video camera to get the data accurately on the pretest and the posttest session. The test will utilize imperatives questions based on the picture, body language, and oral test. The marking schema that was used to measure the speaking ability of the student' fluency in conversation and imperatives of this study was adopted from Ur (1996). The band score could be seen in the following table: 
Table 1. The Band Score for Speaking Fluency

\begin{tabular}{|l|c|}
\hline \multicolumn{1}{|c|}{ Fluency } & Score \\
\hline 1. Little or no communication & 1 \\
2. Very hesitant and brief utterance sometimes & 2 \\
difficult to understand. & 3 \\
3. Get the idea across, but hesitantly and briefly & 4 \\
4. Effective communication in the short term. & 5 \\
5. Easy and effective communication use long & \\
term. & \\
\hline
\end{tabular}

The criteria of student's speaking ability as follow:

$$
\begin{aligned}
& 5=\text { Very Good } \\
& 4=\text { Good } \\
& 3=\text { Moderate } \\
& 2=\text { Poor } \\
& 1=\text { Very Poor }
\end{aligned}
$$

In this study, the researcher used two techniques for analyzing the data. They were an inferential statistic and descriptive statistics. The inferential statistic was used to examine the hypothesis, while the descriptive is used to the students characteristics such as mean score, frequency, minimum, maximum, and range score in both pretest and posttest and to know of the use of total physical response technique in teaching of speaking, the researcher used onetailed t-test with formulas as follows:

$$
t=\frac{\overline{\mathrm{D}}}{\sqrt{\frac{\sum \mathrm{D}^{2}-\frac{\left(\sum \mathrm{D}\right)^{2}}{\mathrm{~N}}}{\mathrm{~N}-1)}}}
$$

Figure 1. T-two tailed t-test

Where :

$\mathrm{t}=\mathrm{t}$ score for non independent (correlation) means

$\mathrm{D}=$ the score difference between pre and post-test

$\bar{D}=$ the mean score of differences score

$\sum D^{2}=$ the sum of differences

$\mathrm{N}=$ number of sample

Arikunto (2010) 
The testing criteria as follows:

1. If $\mathrm{t}$-test $>\mathrm{t}$ table, the hypothesis is accepted. It means that there is a significant effect of the total physical response technique in teaching speaking to the first-grade students of SMA Negeri 2 Kolaka.

2. If $\mathrm{t}$-test $<\mathrm{t}$ table, the hypothesis is rejected. It means that there is not a significant effect of the use total physical response technique in teaching speaking to the first-grade students of SMA Negeri 2 Kolaka.

\section{RESULT AND DISCUSSIONS}

\section{Findings}

Table 2. The Different Between Pre Test and Post Test

\begin{tabular}{|c|c|c|c|c|c|c|}
\hline & Mean & Median & $\begin{array}{c}\text { Standar } \\
\text { Deviation }\end{array}$ & Variance & Minimum & Maximum \\
\hline $\begin{array}{c}\text { Pre- } \\
\text { test }\end{array}$ & 2,25 & 2 & 0,668 & 0,446 & 1,5 & 4 \\
\hline $\begin{array}{c}\text { Post- } \\
\text { test }\end{array}$ & 3,9 & 4 & 0,541 & 0,293 & 3 & 5 \\
\hline
\end{tabular}

Based on table 2, it was found that the mean score of the pretest $(2,25)$. It got from the total final value of pre-test allotted total number of students and the mean score of post-test $(3,9)$. It got from the total final value of post-test allotted total number of students, the median score of pre-test (2) and the median score of post-test (4), the standard deviation of pre-test $(0,668)$, and the standard deviation of post-test $(0,541)$, the variance score of pre-test $(0,446)$, and the variance score of post-test $(0,293)$, the minimum score of pre-test $(1,5)$, and the minimum score of post-test (3), the maximum score of pre-test (4), and the maximum score of post-test (5). For more details see appendix 8 on page 73 and appendix 9 on page 75 data pre-test and post-test.

The criteria of hypothesis testing stated that if $\mathrm{t}$-test $\geq \mathrm{t}$ table, $\mathrm{H}_{1}$ is accepted, and $\mathrm{H}_{0}$ is rejected and if t-test $\leq \mathrm{t}$ table, $\mathrm{H}_{1}$ is rejected, and $\mathrm{H}_{0}$ is accepted. Summary of hypothesis testing can be seen in table below :

Table 3. Summary of Hypothesis Testing

\begin{tabular}{|c|c|c|c|}
\hline \multicolumn{3}{|c|}{ Statistic } & Result \\
\hline Df & $t_{\text {count }}$ & $t_{\text {table }}$ & $\mathrm{t}_{\text {count }}>\mathrm{t}_{\text {table }}$ \\
\hline 21 & 11,2 & 2,080 & $\begin{array}{l}\mathrm{H}_{0}=\text { Rejected } \\
\mathrm{H}_{1}=\text { Accepted }\end{array}$ \\
\hline
\end{tabular}

Hypothesis testing used to investigate whether there is an effect of Total Physical Response technique toward the students' speaking ability at the 
First-grade of SMA Negeri 2 Kolaka. Based on the computation of t-test found that $\mathbf{t}_{\text {count }}$ was 11,2 it consulted to the $\mathbf{t}_{\text {table }}$ at the significant level $(\alpha) 0,05$ and degree of freedom $21=2,080$. It found that tcount was higher than table. So, $\mathrm{H} 1$ was accepted, and $\mathrm{H} 0$ was rejected which was mean that there is an effect of Total Physical Response technique toward the students' speaking ability at the first grade of SMA Negeri 2 Kolaka.

\section{Discussion}

The improvement of students' speaking ability in this study might be due to several factors. They were direct role, active role, and comprehension. The teacher is the director of all student behavior and the director of a stage play in which the students are the actors. The teacher or instructor first gives a model as she/he action (Asher, 1986: 43). As what would be happening in applying Total Physical Response.

The result of this study shows that there is an effect of total physical response technique toward the students' speaking ability in the first-grade of SMA Negeri 2 Kolaka. It could be proven that the tcount was higher than table. The different indicates that there is an effect of total physical response technique toward the students' speaking ability at the first grade of SMA Negeri 2 Kolaka, because by total physical response technique in teaching speaking, the students' can interaction use a command and action with each other students' and could help students' to understand the command by their action. Besides that, the total physical response technique also helped the students' comprehension in speaking fluently by using some given commands. In addition, the students' with their partner practice the procedure text by fluently.

The general objectives of total physical response are to teach oral proficiency at a beginning level. Richards and Rodgers (2001) explain another sub-goal of the method are introducing a new vocabulary item to the student through body movement, to arose the students to enjoy their experience in learning foreign language, to reduce the students stressed felling when they are studying a foreign language, to get the students to recognize or identify the word that has been thought, using comprehension as a means to speak, and using action-based drills is the imperative form. Heaton (1989) says that pair work as one strategy in teaching English because it immediately increases the amount of student practice. The total participants of class are twenty-two students we can immediately see that at any time eleven students are taking at one instead of one. Pair work allows the students to use language and also encourages student cooperation which it self important for the atmosphere of the class and the motivation it gives to learn with the others.

The implementation of total physical response technique in teaching speaking that to improve the students' speaking ability at the first grade of SMA Negeri 2 Kolaka was success after gave treatment with applied total physical response technique. 


\section{CONCLUSIONS, IMPLICATION, AND SUGGESTIONS}

Based on the findings and discussions of the research of students' anxiety in speaking English at MAN 1 Kolaka, it can be concluded that the factors caused students anxiety in speaking English that mostly influent students in learning English were communicative apprehension with mean value $(3,82)$ The second factors was fear of negative evaluation with mean value $(3,67)$ the last factors was test anxiety with mean value (3,4). Furthermore, students overcome anxiety in speaking English using five strategies namely: preparation, relaxation, positive thinking, peer seeking and resignation.

\section{REFERENCES}

Arikunto. (2010). Prosedur Penelitian Suatu Pendekatan Praktik. Jakarta: Rineka Cipta.

Asher, J. (1986). Learning Another Language Through Actions: the complete Teacher's Guidebook. Los gatos, Calif: Sky Oaks Publications.

Bailey, K.M. (2005). Practical English Language Teaching: Speaking. Boston: McGraw-Hill.

Chastain, K. (1998). Developing second language skills (2nd Ed.). Chicago: Harcourt Brace Publishers.

Frankel, J. R. and N. E. Wallen. (1990). How to Design and Evaluate Research in education. USA: Mc Graw-Hill. Incorporation Inc.

Heaton, James Ben. (1989). Writing English Language Tests. UK: Longman Publishers, Print.

ISAAC, S., \& Michael, W. B. (1981). Handbook in Research and Evaluation. San diego: EdITS Publishers.

Nunan, D. 1992. Research Methods in Language Learning. Cambridge: Cambridge University Press.

Richards, J. C., \& Rodgers, T. S. (2001). Approaches and Methods in Language Teaching (2nd ed.). Cambridge: Cambridge University Press

Ur, P. (1996). A Course in Language Teaching: Practice and Theory. United Kingdom: Cambridge University press. 